AL IBTIDA: JURNAL PENDIDIKAN GURU MI (2019) Vol 6 (2): 177-190

DOI: http://dx.doi.org/ 10.24235/al.ibtida.snj.v6i2.4173

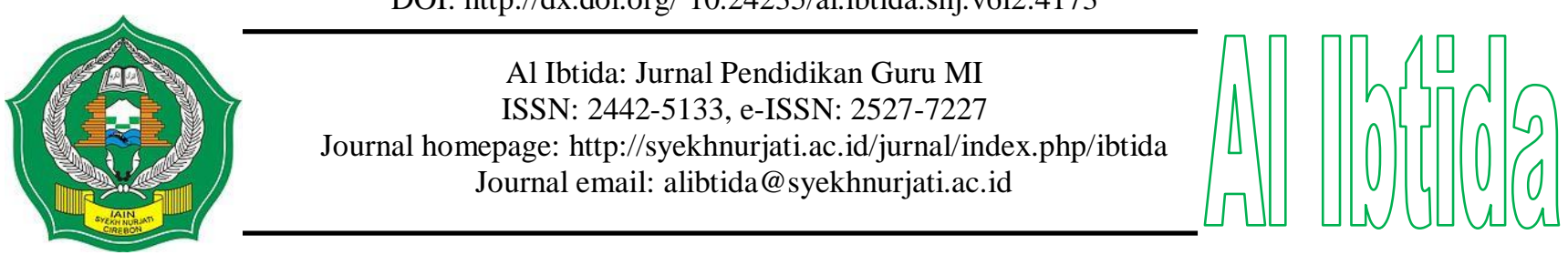

\title{
Developing Interactive Multimedia Through Ispring on Indonesian Learning with the Insight Islamic Values in Madrasah Ibtidaiyah
}

\author{
Muchamad Fauyan* \\ *Department of Madrasah Ibtidaiyah Teacher Education, Faculty of Tarbiyah and Teacher Training, \\ Institut Agama Islam Negeri Pekalongan \\ Email: muchamad.fauyan@iainpkl.ac.id
}

Received: May 06 ${ }^{\text {th }}, 2019$. Accepted: October $14^{\text {th }}, 2019$. Published: October 29 2019.

\begin{abstract}
This research was motivated by the Indonesian learning which contains very little of moral and character messages and the lack of learning resources, resulting in less interesting and unpleasant learning which lead the development of four aspects of language skills as learning objectives to be unachieved. Therefore, this research aimed to find out (1) the eligibility of interactive multimedia on Indonesian learning with Islamic insight based on the assessment of media experts and material experts, and (2) the quality of interactive multimedia on Indonesian learning with Islamic insight based on the assessment of students and teachers. This research and development are using ADDIE model. The procedures of this research include the stages of analysis, design, development, implementation, and evaluation. The subjects of this study were fourth grade students of Madrasah Ibtidaiyah (MI) Pringlangu 02 Pekalongan City. The results of this study are: (1) interactive multimedia products for Indonesian learning with Islamic insight was assessed by material experts with a score of 21.5 in the very eligible category and assessed by media experts with a score of 49.5 in the eligible category; (2) the quality of interactive multimedia for Indonesian learning with Islamic insight is very good based on the assessment of students and teachers. Thus, the use of multimedia for Indonesian learning is needed because it is a source of learning that can improve learning performance, as well as seeding the value of Islamic characters in students.
\end{abstract}

Keywords: interactive multimedia, indonesian learning, Islamic values.

\begin{abstract}
Abstrak
Penelitian ini dilatarbelakangi oleh pembelajaran bahasa Indonesia yang kering dari pesan-pesan moral dan karakter serta minimnya sumber belajar yang mengakibatkan pembelajarannya kurang menarik dan tidak menyenangkan yang pada gilirannya pengembangan empat aspek keterampilan berbahasa sebagai tujuan pembelajaran tidak tercapai. Oleh karena itu, penelitian ini bertujuan untuk menghasilkan (1) kelayakan multimedia interaktif pada pembelajaran bahasa Indonesia berwawasan nilai-nilai Islami berdasarkan penilaian ahli guru dan siswa, dan (2) kualitas multimedia interaktif pada pembelajaran bahasa Indonesia berwawasan nilai-nilai Islami berdasarkan penilaian siswa dan guru. Penelitian pengembangan ini (Research and Development) menggunakan model ADDIE. Prosedur penelitian ini
\end{abstract}


meliputi: tahap analisis, desain, pengembangan, implementasi, dan evaluasi. Subjek penelitian ini adalah siswa kelas IV Madrasah Ibtidaiyah (MI) Pringlangu 02 Kota Pekalongan. Hasil penelitian ini adalah: (1) produk multimedia interaktif untuk pembelajaran bahasa Indonesia berwawasan nilai-nilai Islami dinilai oleh ahli materi dengan skor 21,5 berada pada kategori sangat layak dan dinilai oleh ahli media dengan skor 49,5 berada pada kategori layak; (2) kualitas multimedia interaktif untuk pembelajaran bahasa Indonesia berwawasan nilai-nilai Islami adalah sangat baik berdasarkan penilaian siswa dan guru. Dengan demikian, penggunaan multimedia pada pembelajaran bahasa Indonesia diperlukan karena menjadi sumber belajar yang mampu meningkatkan kinerja pembelajaran, sekaligus penyemai nilainilai karakter Islami pada siswa.

Kata kunci: multimedia interaktif, pembelajaran bahasa Indonesia, nlai-nilai Islam.

\section{INTRODUCTION}

Indonesian learning in Elementary School or Madrasah Ibtidaiyah in Curriculum 2013 is conducted thematically, i.e. Indonesian subject is integrated with other subjects, yet it is not included in Islamic Education subjects. It leads the thematic learning focused on the achievement of competencies which tend to cover the cognitive aspects only, while the aspects of spiritual and social attitudes have not been developed by many teachers. Consequently, Indonesian learning, which is integrated with other subjects, becomes a lack of moral or social attitude messages, especially Islamic values and spiritual attitudes. In fact, Indonesian has been philosophically reviewed as having transcendent values that are contained in many verses of the Quran (Anshori, n.d.).

From a survey that the researcher conducted by involving students in Indonesian learning lectures in the even semester of the academic year 2016/2017, the data related to difficulties on Indonesian learning in elementary school/ Islamic elementary school were obtained from Indonesian teachers and students of Pekalongan. Generally, the respondents stated that the most difficult and hindering aspect of Indonesian learning for students and teachers was writing. It is certainly understandable that there are factors causing this to happen. Graves in Suparno \& Yunus (2007) stated that the students' negative impacts on learning Indonesian experience was caused by teachers who are less motivating students. Teachers rarely stimulate students' interest and learning potency, and it is also influenced by family and community environment.

The general problem of Indonesian learning in elementary school or Islamic elementary school in Pekalongan is also experienced in Islamic Elementary School Pringlangu 02 Pekalongan. Based on the needs analysis with fourth-grade teachers, it was found out that the problem was the fourth-grade students' unsatisfactory scores in Indonesian. In learning descriptive text, based on the basic competence in Curriculum 2013, it is proven that students are 
not accustomed to asking questions about unique and interesting things from their surroundings. In other words, students have not been motivated to write stories or descriptions about the environment or natural resources in their area.

Based on the analysis of the problem, it is noticed that the contributing factor is the conventional method, in this case, using the grammatical approach, employed to teach students. The improper strategy used also complicated students to find vocabularies and arrange them into sentences. In practice, teachers are suggested to use various methods in teaching writing. In addition, teachers need to propose students to write, think, and control their writing instead of think, write, and control method. As stated by Abidin (2013), we just need to write anything, anywhere, anytime, before revising it with thought, and edit through spelling control and other writing technical guidelines. .

The lack of optimal learning outcomes of the fourth-grade students are also influenced by the teachers' lack of utilizing media/teaching aids to support Indonesian learning due to the limited facilities. In addition, the learning process in Islamic Elementary School Pringlangu was teacher-centered, where teachers having a major role in teaching and learning. However, according to Arsyad (2011), teachers should not only focus on textbooks, but they must develop materials according to the information needed by students using interactive multimedia.

Interactive multimedia can be interpreted as a learning tool or medium that contains material, methods, boundaries, and ways of evaluating designed systematically and attractively to achieve competencies/sub-competencies expected according to complexity level (Arsyad, 2011). According to Anitah in Nugraha (2017), interactive media is a system of presenting lessons with visual, audio, and video material to facilitate students not only to hear sounds and see images, but also give active responses. In other words, multimedia is an interactive tool since it is equipped with a controller that can be operated to choose the next process.

Some of the advantages in interactive multimedia include being able to foster students' creativity, critical thinking, curiosity and attraction (Nugraha, Binadja, \& Supartono, 2013), attentiveness (Ramansyah, 2014) and (Arindiono \& Ramadhani, 2013), interest and motivation to learn (Prawiro \& Irawan, 2012), as well as helping students to overcome the limitations of space and time by using the acquired information or abstract processes in learning (Chuntala, 2019); (Nurjaman, Hamdu2, \& Elan, 2018).

Considering the advantages of multimedia, many studies highlight the benefits of multimedia in helping students to improve learning performance. Illahi, Sukartiningsing \& Subroto (2018) stated that there were significant differences in students' critical thinking skills using PPT-based interactive multimedia. Furthermore, Ahmadi, Sutaryono, Wiranto \& Ratnaningrum (2017) in their research article revealed that the development of a multimedia- 
based learning media using Macromedia Flash 8 software could also maximize the quality of education, especially the learning process in primary schools to know, to love and to appreciate national cultural values. Another research by Syamsiah (2017) and Hernaningtyas, Susetyarini, and Widodo (2014) conveyed that making multimedia-based learning applications using Macromedia Flash software can facilitate students to learn edutainment concepts.

Referring to the previous research and the problems in Pringlangu 02 Islamic Elementary School, it is necessary to embed character values in Indonesian learning. As stated by Anshori (n.d.), character coaching of faith and devotion through Indonesian learning can be conducted in two ways. Firstly, the transformation of transcendent (religious) values by the teacher during the language learning process is accomplished implicitly and explicitly. Secondly, the teaching materials should be selected based on the integration between Imtaq (faith and devotion aspect) and Science and Technology. Therefore, the researcher is encouraged to conduct research and development of interactive multimedia in Indonesian learning based on Islamic values for fourthgrade students under the theme "Tempat Tinggalku". Different from the previous research, this study combined national cultural characters with Islamic values and culture of Pekalongan.

\section{METHODS}

This research design employed in this study was research and development. The development procedure in this research followed the stages of the ADDIE model. In general, the multimedia development stages of ADDIE model according to Lee \& Owens (2002), includes analyzing, designing, developing, implementing, and evaluating. This model was chosen since the ADDIE model has systematic procedures with each step always refers to the adjusted previous step to obtain the effective product (Hanifah, Arifuddin, Walid, Padil, Bashith, \& Busro, 2019).

The analyzing stage was conducted by analyzing the competencies that students need, the characteristics of students related to their learning capacity, knowledge, skills, and attitudes, and the materials in accordance with the demanded competencies. The designing stage was conducted by referring to some criteria, namely students, competencies, learning strategies, and assessment and evaluation. The developing stage includes the activity of collecting interactive multimedia-based learning media/materials, illustrating images, typing, and etc. The following activity is creating interactive multimedia-based learning media using software. The fourth stage of the activity is implementing, which was intended to produce good multimedia learning product. Trial in limited class and expanded class were applied to produce good multimedia learning product. The last stage is evaluating, which includes formative evaluation and summative evaluation. 
The subjects of this research were fourth-grade students of Islamic Elementary School Pringlangu 02 Pekalongan in the academic year 2017/2018. The research method used in this study was experimental method with pretest and posttest one group design. The data collection technique includes test and non-test techniques such as interviews, observations, questionnaires, and documentation. The test technique was used to determine the students' achievement in the basic competencies taught and know the condition of their language skills after participating in the learning. Non-technical technique was used to determine the eligibility of interactive learning multimedia in Indonesian learning using map-based on Islamic values through material experts and media experts' assessment. Furthermore, the non-technical technique was used to find students and teachers' responses towards the developed interactive learning multimedia.

The data were analyzed by using descriptive qualitative and quantitative. These techniques were employed to determine the eligibility and quality of multimedia interactive learning. The data on interactive learning multimedia eligibility in Indonesian learning with the insight of Islamic values were obtained through the assessment conducted by material experts and media experts. On the other hand, data on students' assessment responses were obtained through the results of field trials. The data were obtained through a questionnaire using Likert scale of four answer choices. Moreover, the scores obtained were converted into scores that can be categorized according to the assessment criteria. These assessment criteria were adapted from Nurgiyantoro's framework (2012), and the four assessment criteria are very eligible / very good, eligible / good, eligible enough / good enough, inadequate / not good.

\section{RESULTS AND DISCUSSION}

\section{Data Analysis of Interactive Multimedia with Embedded Islamic Values}

Interactive multimedia development data analysis is conducted to analyze the validation data provided by material experts and media experts whose aim is to determine the eligibility level of the developing interactive learning multimedia product.

1. Analysis of Material Experts' Validation Results

The material expert validation was conducted by two material experts; a lecturer of the Tarbiyah and Teacher Training Faculty (FTIK) and a teacher of Islamic Elementary School Pringlangu 02. Both material experts agreed that the interactive learning multimedia of map material is very eligible to use. The validation data given by material experts in the form of scores were converted into interval scores of four scale. Based on the material experts' validation data, it is known that the highest ideal score is 24 , the lowest ideal score is 6 and the ideal standard deviation is 3. The result of material experts' validation is presented in the following table 1. 
Table 1. The data of Material Experts' Validation Results

\begin{tabular}{clcc}
\hline No. & \multicolumn{1}{c}{ Aspects } & Average Score & Category \\
\hline 1 & Content & 21,5 & Very Eligible \\
2 & Learning Instructions & 21,5 & Very Eligible \\
\hline & Average Score & 21,5 & Very Eligible \\
\hline
\end{tabular}

Table 1 highlights the average score obtained from the material experts, which is 21.5, and considered as very eligible. Hence, the interactive learning multimedia product on Indonesian learning is considered to be in the category of "very eligible to be tested". Interactive learning multimedia for recognizing map with embedded Islamic values was considered eligible to be tested by material experts and media experts on Indonesian subjects since they meet two expected aspects, namely material and media aspects. The information that must be available in multimedia learning to be eligible, namely, competence, material presentation, and evaluation are integrated with Islamic values.

Interactive learning multimedia material of recognizing map was developed based on basic competencies indicators. They can be found in the following basic competencies, namely: (a) make a map based on the explanation being learned, (b) describe the instruction verbally on the use of a tool (map) with correct and coherent word choice. Interactive learning multimedia material of recognizing a map has three main presentations, namely: material, simulation, and evaluation. The material presentation has three sub materials that will be studied in accordance with basic competencies, namely: map, description, and report. There are ten questions divided into two parts, which are then displayed in sequence every time users enter the evaluation page. The evaluation program also provides feedback on the users' answers. The five questions of the second part display the final score of the evaluation results with visual basic macros support in the developing ppt program. For the simulation presentation, there is a picture of a child and the description of his journey from home to school.

2. Analysis of Media Expert Validation Results

The validation of media experts was conducted by two media experts from the Faculty of Information and Communication Engineering lecturers. Both media experts concluded that the map interactive learning multimedia material was appropriate to be used with revisions, as suggested. Based on validation data by material experts, it is known that the highest ideal score is 68 , the lowest ideal score is 17 , and the ideal standard deviation is 8,5. The results of the conversion of the average four-scale score is displayed in table 2 . 
Table 2. The Data of Media Expert Validation Results

\begin{tabular}{|c|c|c|c|}
\hline No. & Aspects & Average Score & Category \\
\hline 1 & Integration & 9 & Eligible \\
\hline 2 & Balance & 8 & Eligible \\
\hline 3 & Font & 10 & Eligible \\
\hline 4 & Color & 9 & Eligible \\
\hline 5 & Language & 8 & Eligible \\
\hline \multirow[t]{2}{*}{6} & Interactive & 5,5 & Eligible \\
\hline & Total Average Score & 49,5 & Eligible \\
\hline
\end{tabular}

The table 2 above highlights the average score obtained from media experts which is 49,5 in the"eligible" category. Therefore, it can be concluded that interactive learning multimedia product on Indonesian learning is very eligible to be tested. Interactive learning multimedia in recognizing floor plan is considered eligible by media experts to be tested on Indonesian subjects with the embedded Islamic values because they fulfill the aspects of media requirements. There are a number of criteria that have been met, namely ease of use, display quality, benefits and appropriateness of text, images, audio, video, animation, and simulation of the material. The findings of this research by utilizing animated figures of Islamic children are emphasized by a study conducted by Palilonis \& Watt (2019). They stated that a digital novel in teaching website that utilizes the popularity of one of the cartoon characters is introduced to meet the challenges of the 21 st century.

\section{Student Responses to the Quality of Interactive Multimedia with Embedded Islamic Values}

At the time of the trial, questionnaires were distributed to 28 fourth grade students who were the subjects in this research. The student questionnaires were given to students to determine their responses to the quality of the use of interactive multimedia in recognizing map. From the available data, it can be noticed that the ideal highest score is 1578 , while the lowest ideal score is 17 .

Table 3. Student Response Results to the Quality of Learning Media

\begin{tabular}{clccc}
\hline No. & \multicolumn{1}{c}{ Variable } & Max Score & Score & Category \\
\hline 1. & $\begin{array}{l}\text { Quality of Content and } \\
\text { Objectives }\end{array}$ & 540 & 470 & Very Good \\
2. & Technical quality & 756 & 653 & Very Good \\
3. Quality of Learning & 540 & 455 & Very Good \\
& Process
\end{tabular}

Table 3 obtained 470 results for content and objectives quality aspects, 653 results for technical quality aspects, and 455 results for learning process quality aspects. Hence, according to the students' response, the interactive learning multimedia product on Indonesian learning is included in the category of "very good". 
The results of students' responses indicated that interactive learning multimedia production for Indonesian learning is considered as "very good" due to the aspects of the media, the main menu, material, evaluation, and simulation arranged on a separate page which allows the text in the material and evaluation to be read clearly. The quality of display on interactive multimedia learning pages is presented with harmonious color compositions to attract students' attention. Color can affect their psychological aspects, and it can also be related to the topic. The colors in the development of multimedia learning were various to make it look lively, and more attractive which is suitable for four grade students. However, the dominant color selected in the development of multimedia is green because it is identical to the fresh impression, and it represents the color of the IAIN Pekalongan and Faculty of Information and Communication Engineering flags. The images and animations presented in this multimedia are intended to illustrate the information that is difficult for students to understand as well as to grab students' focus.

Images, audios, and videos are media that can be used to enhance motivation in learning. They can be used to attract students' attention, for example, at the beginning to the end of interactive learning multimedia. Therefore, cheerful and uplifting background images, audio, and video are selected in this interactive learning multimedia to make students interested in listening and following the media flow. Audio and video in this multimedia are in the form of audio, video, and movements of the song "Arah Mata Angin" and "Ciri-Ciri Map" combined with the song of shalawat. This study is in line with another study conducted by Kim \& Lee (2016) which found out that the use of images, animation and sound in interactive story books (iStory Book) is able to support dialogue readings between parents and children so that children are enthusiastic about learning without feeling excessive demands.

\section{Teacher Responses to the Quality of Interactive Multimedia Development}

Based on the data of teacher responses, it is known that the ideal highest score is 66, and the lowest ideal score is 19 . The detail of the teachers' response is presented below.

Table 4. Teacher Response Results towards Learning Media

\begin{tabular}{clccc}
\hline No. & \multicolumn{1}{c}{ Variable } & Max Score & Score & Category \\
\hline 1. & Quality of Content and & 24 & 20 & Very Good \\
& $\begin{array}{l}\text { Objectives } \\
\text { 2. }\end{array}$ & 28 & 26 & Very Good \\
3. & $\begin{array}{l}\text { Quality of Learning } \\
\text { Process }\end{array}$ & 24 & 20 & Very Good \\
\hline
\end{tabular}

Table 4 obtained 20 results for contents and objectives quality aspects, 26 results for technical quality aspect, 20 results on the quality of the learning process aspect. Accordingly, the 
teachers' response towards the quality of interactive learning multimedia products on Indonesian learning is categorized as "very good".

The results of the teacher's response were due to the aspects of the media, the main menu, material, evaluation, and simulation arranged on separate pages. In the material menu, apperception is presented first and followed by the introduction to the theory on each subject, which is associated with Islamic values. The activity was ended with an exercise to reinforce student understanding. The results of this development are in line with a study conducted by Kusmaryono \& Maharani (2017). They discovered that learning Islamic character subconsciously is a process of character building through mathematics lessons.

\section{Product Review of Interactive Multimedia}

This development research yields a product in the form of interactive learning multimedia applications with the embedded Islamic values on Indonesian learning in exe format. Interactive learning multimedia of "map material" is used for Indonesian subject learning of fourth-grade students in elementary or Islamic elementary school with the basic competency of "presenting an adventure narrative text about the environment and natural resources independently in spoken and written Indonesian text by selecting and sorting standard vocabulary ".

The following is the visual description of interactive learning multimedia for Indonesian learning with the embedded Islamic values final product. The pictures below contain the opening page, the main menu, and the competencies, material, simulations, and evaluation pages.

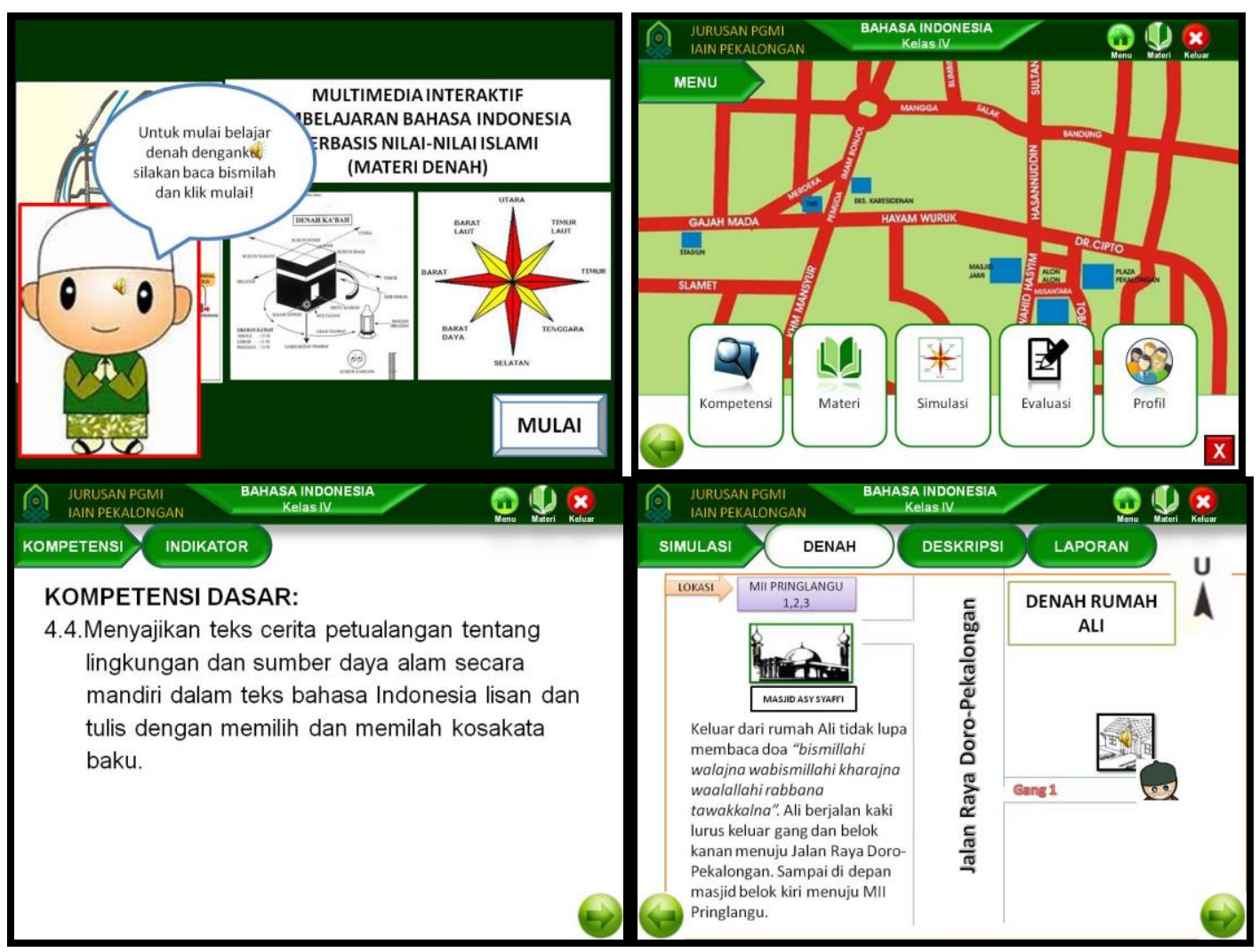




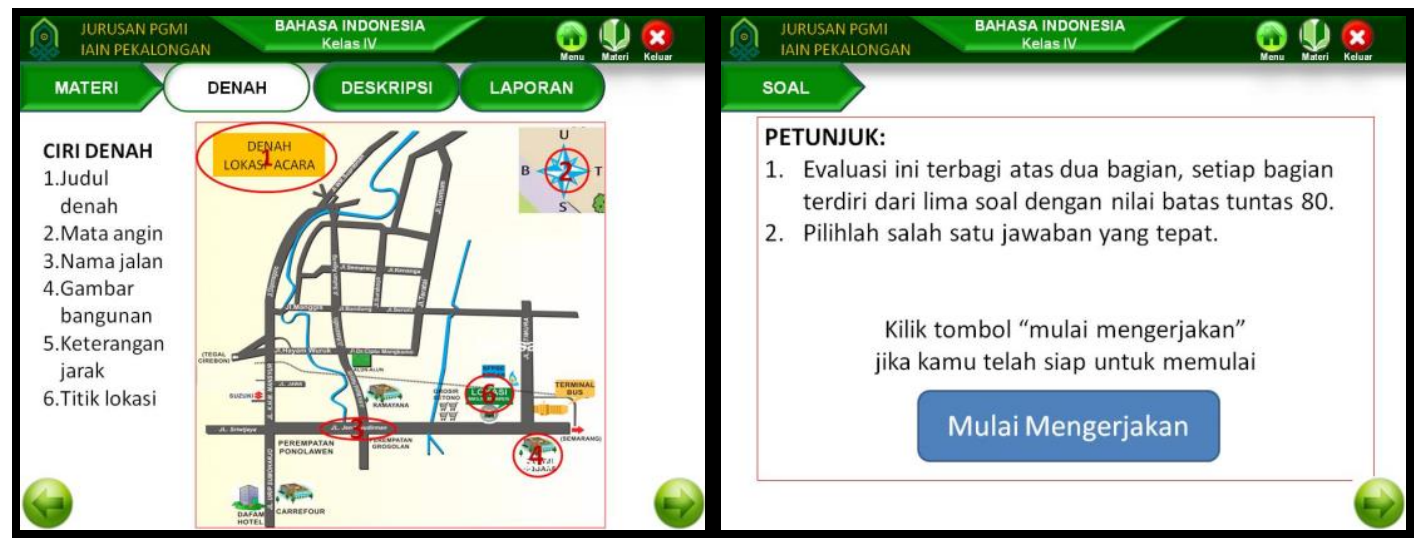

Figure 1. The Final Visual of the Interactive Learning Multimedia

Based on the results of research and development, it is known that the product is in the form of interactive learning multimedia applications on Indonesian learning with embedded Islamic values for "map" material. This learning multimedia product is in the form of ppt files that have been published through Ispring 8 in the format of exe which is stored on a CD. This multimedia product does not use a learning media guidebook, while research by Rosita (2015) used a learning media guidebook that contains steps to use speaking media properly. This multimedia production was developed in accordance with the ADDIE model, namely, Analysis, Design, Development, Implementation, and Evaluation. The process of developing this learning multimedia has been through several years of development and validation from experts. Therefore, a final product that is eligible to be applied in the learning process is obtained. The development of a multimedia product using the ADDIE model is similar to a study conducted by Febryan, Santyasa, \& Tegeh (2016), which utilized ADDIE model in producing SRL (Self Regulated Learning) based interactive multimedia product for art and culture subject to thirdgrade students. The product was validated through expert validation and subject teachers and students' response on the trial.

Furthermore, the media developed in this study was integrated with Islamic values to provide students in elementary and Islamic elementary school. This is in accordance with a notion by Anshori (n.d), who affirmed that language learning in the context of fostering faith and devotion could be organized by selecting teaching materials in lined with the principles, as well as fostering language teachers for these values. Based on his notion, it can be implied that Indonesian teacher does not only teach languages but also teaches Islamic values and characters both explicitly and implicitly. Moreover, it emphasizes the role of teachers in transforming religious values through Indonesian learning.

In the practice of developing multimedia-based on Islamic values, the researcher has tried to organize the Indonesian learning by planning the lesson and associating it with the materials 
related to Islamic contents such as Asmaul Husna, five pillars of Islam, Islamic names, Islamic figure, and other topics with Islamic values. Yasri (2013) explained that instilling the Islamic values can be conducted in various ways, specifically mentioning the name of Allah, presenting visual illustrations, giving examples, inserting relevant verses of Quran or hadiths, tracking history, and providing various topics. The material development in this study was also strengthened by a study carried out by Kusmaryono \& Maharani (2017) which used several methods to internalize Islamic values, namely: (a) infusion; the teacher emphasizes aspects of the value of the Quran embedded in the material, (b) analogy; the teacher creates an analogy of the value of kindness, (c) narration; the teacher tells stories related to mathematics and Muslim Mathematicians to take the moral value, and (d) uswah hasanah; the teacher shows behaviors related to Mathematics such as honesty, sincerity, accuracy, observance, and carefulness.

This research was intended to develop students' language skills and character-building through the introduction of an insightful map of Islamic values and the local culture of Pekalongan. This study has a common goal with Ahmadi et al. (2017) which is to increase the character-building process of elementary school students by allowing them to be more familiar with the audio-visual of Indonesian culture through the development of multimedia using Macromedia Flash 8 software. This research is also strengthened by a study administered by Buchori \& Setyawati (2015) about the "Learning Model of character building through E-Comic in Elementary Schools" that found the use of e-comic multimedia is effective in building students' character. The effectiveness is recognized from the increasing of characteristic values in students through observation and learning assessment.

Overall, the appropriate assessment for interactive learning multimedia with the embedded Islamic values cannot be separated from its function and benefits as a learning medium to develop students' language skills and character-building through recognizing map material. The function and benefits of using this learning media are to clarify and facilitate the delivery of map material, enhance students' learning motivation, and attract their attention. The conclusion of this study is in line with the results of research conducted Paseleng \& Arifiyani (2015), Nugraha (2017), Muin (2017), Fajri (2018), and Mukmin \& Zunaidah (2018) which can be concluded that interactive media used in learning process can attract students to share and acquire information so that they can understand the learning material better.

In addition, this developing multimedia also strengthen students' quick and considerable responses and participation during the learning process, as in the research of Asad, Tibi, \& Raiyn (2016). They highlighted that by using interactive multimedia, students' attitudes become positive, and it improves their problem-solving skills. Besides, the use of interactive multimedia can help students in reflecting Islamic characters by communicating using effective and 
communicative language with the reasoning ability based on the principles of Islamic communication stated in An Nisa verse 63 of the Quran to prescribe language activities that are valuable to worship. The findings of the researcher are in line with research by Nopiarti, (2015) which found out that the internalization of Islamic values in Indonesian learning is conducted by combining the material taught in each language skill with materials containing Islamic values for moral and character building.

\section{CONCLUSION}

Based on the result of this study, it can be concluded that the product developed is interactive learning multimedia with embedded Islamic values that have been tested for its eligibility. This media can be used for Indonesian learning process for the second semester of fourth-grade students of Islamic Elementary School. The product is a ppt file developed by using ADDIE model that has been published in an output flash and exe format stored in a CD. The learning multimedia for Indonesian learning with the embedded Islamic values was developed based on needs analysis and front-end analysis by adjusting the characteristics of students and integrating Islamic values and contextualizing them with the environment of Pekalongan. Therefore, if it is used in other areas, or when there are deficiencies found to be repaired, it is advisable to revise as necessary. It is also recommended that the use of this interactive learning multimedia is supported by other relevant learning sources such as maps, visual aids, and etc, so that it is not taken as the only source of learning for students.

\section{REFERENCES}

Abidin, Y. (2013). Pembelajaran Bahasa Berwawasan Pendidikan Karakter. Bandung: Aditama.

Ahmadi, F., Sutaryono, Wiranto, Y., \& Ratnaningrum, I. (2017). "Pengembangan Media Edukasi 'Multimedia Indonesian Culture' (MIC) Sebagai Penguatan Pendidikan Karakter Siswa Sekolah Dasar.” Penelitian Pendidikan, 34(2), 127-136.

Anshori, D. S. (n.d.). Ruh Islam dalam Pembelajaran Bahasa Indonesia. Retrieved July 27, 2017, fromhttp://file.upi.edu/Direktori/FPBS/JUR._PEND._BHS._DAN_SASTRA_INDONES IA/197204031999031-DADANG/maka_bahasa.pdf.

Arindiono, R. J., \& Ramadhani, N. (2013). "Perancangan Media Pembelajaran Interaktif Matematika untuk Siswa Kelas 5 SD.” Jurnal Sains Dan Seni ITS, 2(1), F28-F32.

Arsyad, A. (2011). Media pembelajaran. Jakarta: Rajawali Pres.

Asad, K., Tibi, M., \& Raiyn, J. (2016). Primary School Pupils’ Attitudes toward Learning Programming through Visual Interactive Environments. World Journal of Education, 6(5), 20-26.

Buchori, A., \& Setyawati, R. D. (2015). "Development Model of Character Education through E-comic in Elementary School." International Journal of Education and Research, 3(9), 369-386. 
Chuntala, A. D. W. (2019). International Journal of Active Learning Saintific Approach in 21 st Century Learning in Indonesian Language Learning Vocational School of Pharmacy. International Journal of Active Learning, 4(2).

Febryan, I., Santyasa, I. W., \& Tegeh, I. M. (2016). Pengembangan Multimedia Interaktif Berbasis Self Regulated Learning dengan Model Addie untuk Meningkatkan Prestasi Belajar Seni Budaya Bagi Siswa Kelas VII SMP Negeri 3 Mendoyo. Jurnal Teknologi Pembelajaran Indonesia, 6(1).

Fajri, R. (2018). Multimedia Pembelajaran Interaktif Kesenian Untuk Anak Sekolah Dasar. Jurnal Ilmiah Sains, Teknologi, Ekonomi, Sosial dan Budaya, 2(1), 24-32.

Hanifah, N. H., Arifuddin, A., Walid, M., Padil, M., Bashith, A., \& Busro, B. (2019, March). Developing autoplay media based mathematics teaching materials for elementary school. In Journal of Physics: Conference Series (Vol. 1175, No. 1, p. 012265). IOP Publishing.

Hernaningtyas, I. S., Susetyarini, R. E., \& Widodo, R. (2014). "Pengembangan Multimedia Interaktif Ceria (MIC) Pembelajaran Tematik Di Sekolah Dasar." Jurnal Pemikiran Dan Pengembangan Sekolah Dasar (JP2SD), 1(4), 256-266.

Illahi, T. A. R., Sukartiningsih, W., \& Subroto, W. T. (2018). "Pengembangan Multimedia Interaktif Pada Pembelajaran Materi Jenis-Jenis Pekerjaan untuk Meningkatkan Kemampuan Berpikir Kritis',4(3).

Kim, S., \& Lee, Y. G. (2016). “iStoryBook: An Interactive Media Supporting Dialogic Reading for Children's Reading Comprehension.” International Journal of Multimedia and Ubiquitous Engineering, 11, 383-392.

Kusmaryono, I., \& Maharani, H. R. (2017). "Penerapan Pembelajaran Berkarakter Islami Pada Program PPL Mahasiswa Pendidikan Matematika Unissula Semarang." Suska Journal of Mathematics Education, Vol. 3(No. 2), 119-129.

Lee, W. W., Owens, D. L., \& Benson, A. D. (2002). Design considerations for web-based learning systems. Advances in Developing Human Resources, 4(4), 405-423.

Muin, A. (2017). "Keterampilan Berbasis Multimedia Interaktif Pada Pembelajaran Seni Budaya Di Sekolah Dasar.” Jppi, 20(2007), 133-135.

Mukmin, B. A., \& Zunaidah, F. N. (2018). Pengembangan Bahan Ajar DELIKAN Tematik Berbasis Multimedia Interaktif Untuk Siswa Sekolah Dasar di Kota Kediri. Al Ibtida: Jurnal Pendidikan Guru MI, 5(2), 145.

Nugraha, D. A., Binadja, A., \& Supartono. (2013). Pengembangan Bahan Ajar Reaksi Redoks Bervisi Sets, Berorientasi Konstruktivistik. Journal of Innovative Science Education, 2(1).

Nugraha, R. G. A. (2017). "Pengembangan Media Interaktif Berbasis Adobe Flash Cs4 Professional Pada Pembelajaran Tematik Untuk Siswakelas 2 SD"'. Scholaria, Vol 7(No 2), 94-105.

Nurjaman, A. I., Hamdu2, G., \& Elan. (2018). "Pengembangan Multimedia Interaktif Pelaksanaan Pembelajaran Outdoor Permainan Tradisional Berbasis STEM di SD." Pedadidaktika: Jurnal Ilmiah Pendidikan Guru Sekolah Dasar, 5(3), 85-99.

Palilonis, J., \& Watt, T. (2019). "Professor Garfield's 21 st Century Digital Literacy Project: Supporting K-5 Teachers in their Digital Literacy Instructional Efforts." International Journal on E-Learning, 18(4).

Paseleng, M. C., \& Arfiyani, R. (2015). "Pengimplementasian Media Pembelajaran Berbasis Multimedia Interaktif pada Mata Pelajaran Matematika di Sekolah Dasar." Scholaria, 
5(2), 131-149.

Prawiro, S. A., \& Irawan, A. (2012). "Perancangan Media Pembelajaran Interaktif Ilmu Pengetahuan Alam Untuk Siswa Kelas 4 SD Dengan Metode Learning the Actual Object". Jurnal Sains dan Seni ITS, 1(1), F28-F33. Jurnal Sains dan Seni ITS, 1(1), F28F33.

Ramansyah, W. (2014). "Pengembangan Multimedia Pembelajaran Interaktif Berbasis Adobe Flash CS3 pada Kelas 1 SDN Bancaran 3 Bangkalan.” Edutic-Scientific Journal of Informatics Education, 1(1), 1-11.

Rosita, F. Y. (2015). "Pengembangan Multimedia Interaktif Untuk Pembelajaran Berbicara Bagi Siswa Kelas IV Sekolah Dasar.” JINoP (Jurnal Inovasi Pembelajaran), 1(1), 25-37.

Suparno dan Mohamad Yunus. (2007). Keterampilan Dasar Menulis. Jakarta: Universitas Terbuka.

Syamsiah. (2017). "Pengembangan Aplikasi Multimedia Pembelajaran Interaktif untuk Mata Pelajaran Bahasa Indonesia." Jurnal SAP, 2(1), 53-63.

Umi Nopiarti. (2015). “Internalisasi Nilai-Nilai Islam Untuk Pembentukan Akhlak dalam Pembelajaran Bahasa Indonesia Di Sd Muhammadiyah 16 Karangasem, Laweyan, Surakarta.” 1-23. Retrieved from http://eprints.ums.ac.id/38449/10/Naskah Publikasi.pdf

Yasri. (2013). "Strategi Pembelajaran Matematika Bernuansa Islami.” Retrieved July 27, 2017, from http://bdkpadang.kemenag.go.id/ 